\title{
A REEVALUATION OF THE THRESHOLD EXPOSURE LEVEL OF INHALED JP-8 IN MICE
}

\author{
Bradley R. HERRIN ${ }^{1}$, Jessica E. HALEY ${ }^{1}$, R. Clark LANTZ ${ }^{2}$ and Mark L. WITTEN ${ }^{1}$ \\ ${ }^{I}$ Department of Pediatrics, Arizona Health Sciences Center, The University of Arizona College of Medicine, \\ Room 3354, 1501 N. Campbell Avenue, Tucson, AZ 85724, USA \\ ${ }^{2}$ Department of Cell Biology and Anatomy, The University of Arizona College of Medicine, \\ Tucson, AZ 85724, USA
}

(Received April 15, 2006; Accepted April 27, 2006)

\begin{abstract}
C57BL/6 mice were nose-only exposed to JP-8 jet fuel at average concentrations of 45, 267 , and $406 \mathrm{mg} \mathrm{JP}-8 / \mathrm{m}^{3}$ for $1 \mathrm{hr} / \mathrm{d}$ for 7 days to further test the hypothesis that exposure to JP-8 concentrations below the current permissible exposure level (PEL) of $350 \mathrm{mg} / \mathrm{m}^{3}$ will induce lung injury, and to validate a new "in-line, real-time" total hydrocarbon analysis system capable of measuring both JP-8 vapor and aerosol concentrations. Pulmonary function and respiratory permeability tests were performed 24 to $30 \mathrm{hr}$ after the final exposures. No significant effects were observed at 45 or $267 \mathrm{mg} / \mathrm{m}^{3}$. The only significant effect observed at $406 \mathrm{mg} / \mathrm{m}^{3}$ was a decrease in inspiratory dynamic lung compliance. Morphological examination and morphometric analysis of distal lung tissue demonstrated that alveolar type II epithelial cells showed limited cellular damage with the notable exception of a significant increase in the volume density of lamellar bodies (vacuoles), which is indicative of increased surfactant production, at 45 and $406 \mathrm{mg} / \mathrm{m}^{3}$. The terminal bronchial epithelium showed initial signs of cellular damage, but the morphometric analysis did not quantify these changes as significant. The morphometric analysis techniques appear to provide an increased sensitivity for detecting the deleterious effects of JP-8 as compared to the physiological evidence offered by pulmonary function or respiratory permeability tests. These observations suggest that the current $350 \mathrm{mg} / \mathrm{m}^{3}$ PEL for both JP-8 jet fuel and for other more volatile petroleum distillates should be reevaluated and a lower, more accurate PEL should be established with regard human occupational exposure limits.
\end{abstract}

KEY WORDS: JP-8 jet fuel, Lung injury, Permissible exposure level (PEL), Alveolar type II epithelial cells, Terminal bronchial epithelium, Morphometry

\section{INTRODUCTION}

Jet propellant-8 (JP-8) is the primary jet fuel for both the U.S. Armed Forces and NATO ground-based operations. JP-8 is a kerosene-based fuel adopted by the military as an alternative to replace the more volatile JP-4 jet fuel in efforts to reduce spontaneous and crash-related fires and explosions (Martel, 1987). As the primary fuel, JP-8 represents the most common chemical exposure in the Armed Forces, particularly for flight and ground crew personnel (Pleil et al., 2000). Possible routes of occupational or incidental exposure include pulmonary exposure via inhalation of jet fuel vapors and aerosol, and dermal exposure via direct skin contact. Exposed military personnel have reported a wide variety of jet-fuel induced symptoms, including fatigue, headache, and skin irritation. The currently established occupational exposure limits for JP-8 jet fuel are set by US Air Force/Navy Offices of Safety and Health and by the US Occupational Safety and Health Administration. The permissible exposure limit (PEL) and the short-term exposure limit (STEL) have been set at $350 \mathrm{mg} / \mathrm{m}^{3}$ and $1800 \mathrm{mg} / \mathrm{m}^{3}$, respectively (Agency for Toxic Substances and Disease Registry, 1995; National Research Council, 1996). However, these exposure limits were based on the risks of

Correspondence: Mark L. WITTEN (E-mail: mwitten@peds.arizona.edu) 


\section{B. R. HERRIN et al.}

vapor-only exposures of more-volatile petroleum distillates. The risks of aerosol plus vapor exposure of less-volatile kerosene-based distillates (such as JP-8) were not taken into consideration.

Past studies have linked JP-8 exposure to a multitude of adverse health effects including developmental, hepatic, immunological, neurological, pulmonary, and dermal effects (Cooper and Mattie, 1996; Dossing et al., 1985; Harris et al., 1997; Smith et al., 1997; Pfaff et al., 1995; Ullrich, 1999). However, perhaps of greatest importance are the effects of JP-8 jet fuel on the respiratory system and consequently, pulmonary function. Because jet fuel vapors and aerosol are mainly an inhalation hazard, the major route of jet fuel exposure to flight and ground crew personnel is via the respiratory tract. Multiple studies have examined the effects of JP8 exposure via inhalation. On a physiological level, several studies have demonstrated deleterious effects on pulmonary function including increased pulmonary resistance (Pfaff et al., 1995) and increased respiratory permeability (Robledo and Witten, 1998). On a cellular level, pathological changes including interstitial edema, injured alveolar septa, damaged bronchiolar epithelium and alveolar type II cells, and epithelial necrosis have also been observed, indicating significant cellular damage as a result of JP-8 exposure (Hays et al., 1995; Pfaff et al., 1995; Robledo and Witten, 1998; Robledo et al., 2000). On a biochemical level, altered expression of certain chemical mediators has also been observed, including macrophage inflammatory protein-2 (MIP-2), tumor necrosis factor-alpha (TNF- $\alpha$ ), and anti-inflammatory mediator prostaglan$\operatorname{din} \mathrm{E}_{2}\left(\mathrm{PGE}_{2}\right)$ (Wang et al., 2001). In addition, significant alterations in the expression of proteins related to the maintenance of cellular structure, cellular proliferation, and apoptosis have been noted (Drake et al., 2003).

Despite these adverse effects, few studies have examined the effects of JP-8 exposure at or below the established PEL and STEL levels. However, one recent study provided notable evidence that JP-8 concentrations below the PEL of $350 \mathrm{mg} / \mathrm{m}^{3}$ will induce lung injury (Robledo et al., 2000). In fact, this study indicated initial signs of cellular damage and pulmonary dysfunction at concentrations as low as $50 \mathrm{mg} / \mathrm{m}^{3}$. Such evidence strongly suggests the need for a reevaluation of the current PEL.

The current study was designed to confirm the cytotoxic effects and induced lung injury at JP-8 concentrations below the current PEL identified in earlier studies, to help validate a new "in-line, real-time" total hydrocarbon analysis system capable of more accurately measuring JP-8 vapor and aerosol concentrations, and to define a new PEL for JP-8 in our mouse model. We intended to accomplish these objectives by employing a varied-dose approach involving analysis on a physiological level (pulmonary function and respiratory permeability tests) and on a cellular level (histopathology of the distal lung). Morphometric techniques were used in hopes of quantifying cellular alterations and damage. This study provides further evidence that supports the findings of previous studies that inhalation exposure to JP-8 can induce lung injury at concentrations below the current PEL of $350 \mathrm{mg} / \mathrm{m}^{3}$.

\section{MATERIALS AND METHODS}

\section{Animals}

Male C57BL/6 mice (25-30 g, 4 weeks old, Harlan, Indianapolis, IN, USA) were used in this study. For each exposure concentration, 18 mice were randomly assigned for either JP-8 jet fuel exposure ( $n=$ $12)$ or controls $(n=6)$. All mice were housed in the Association for Accreditation and Assessment of Laboratory Animal Care Institution (AAALAC)-approved animal facility at the University of Arizona College of Medicine. Animals were housed four per cage and were fed ad libitum.

\section{JP-8 Aerosol Generation and Animal Exposure}

A JP-8 blend jet fuel (Lot \# 3509, Wright-Patterson AFB, OH, USA) vapor-aerosol mixture was generated using a Lovelace jet nebulizer (Model 01-100, INTOX, Albuquerque, NM, USA). Jet fuel vapor and aerosol concentrations were measured using an "inline, real-time" total hydrocarbon (THC) analysis system. (VIG Industries, Anaheim, CA, USA). This is in contrast to the generation/measurement methodology employed in previous studies (Pfaff et al., 1996; Robledo and Witten, 1998, Robledo et al., 2000) which used an Ultra-Neb Model 99 nebulizer (DeVilbiss, Somerset, PA, USA) and a 7-stage cascade impactor (0.25 to $5.0 \mu \mathrm{m}$, IN-TOX, Albuquerque, NM, USA) in combination to generate and measure jet fuel aerosol. Such measurement systems are variable and potentially inaccurate, most likely due to the high volatility of JP- 8 and its transition between the aerosol and vapor states. Measurements made using the THC analyzer are significantly more reliable. In this study, for standardization and purposes of comparison between the two measurement systems and with previous studies, the 7 -stage cascade impactor was used in addition to 
A reevaluation of the threshold exposure level of inhaled JP-8 in mice.

the THC analyzer in measuring jet fuel aerosol concentrations. For aerosolized JP-8, the exposure chamber contains 5 to $15 \%$ aerosol droplets of jet fuel and the remainder is vapor (Dietzel et al., 2005). This recent study identified several $\mathrm{N}$-alkanes in the droplets which represents 20 to $70 \%$ of the mass of the droplet. In the vapor, they found several "light end" hydrocarbons including toluene, xylenes, ethylbenzene, and 1, 24-trimethylbenzene in addition to the $\mathrm{N}$-alkanes found in the aerosol phase.

Mice were exposed using a nose-only exposure chamber (24-ports, IN-TOX, Albuquerque, NM, USA) under constant vacuum $(30 \mathrm{~L} / \mathrm{min})$. Animals were exposed for $1 \mathrm{hr}$ per day over a period of 7 consecutive days to average concentrations of 45, 267, and $406 \mathrm{mg} /$ $\mathrm{m}^{3}$. These concentrations are the 7-day averages. Daily exposure concentrations were within 10 percent of the listed target concentrations. Control mice for each group were exposed to ambient air. Exposures were meant to simulate a 7-day work week of intermittent exposure. Nose-only exposures were used to more closely simulate occupational exposures, in addition to minimizing oral ingestion of JP-8 during post-exposure grooming. To maintain the precision and proper calibration of the THC analysis system, exposures were run in succession as opposed to concurrently.

\section{Pulmonary Function and Respiratory Permeability}

The methodologies for measuring pulmonary function and respiratory permeability have been described previously (Robledo and Witten, 1998). Briefly, the mice were anesthetized 24 to $30 \mathrm{hr}$ after the last JP-8 exposure with an intramuscular injection mixture of ketamine HCL ( $80 \mathrm{mg} / \mathrm{kg})$, xylaxine $(10 \mathrm{mg} / \mathrm{kg})$ and acepromazine maleate $(3 \mathrm{mg} / \mathrm{kg})$. Following this, a tracheostomy was performed, inserting a Teflon IV catheter (20 gauge, Critikon, Tampa Bay, FL, USA) as an endotracheal tube. The mice were placed on a small animal ventilator (Kent Scientific, Litchfield, CT, USA) under pressure-controlled ventilation. Airflow was measured with a pneumotachograph (Fleisch \#0000, Instrumentation Associates, New York, NY, USA), which was connected to a differential pressure transducer (Validyne, Northridge, CA, USA). Pulmonary function measurements were obtained using a computerized pulmonary function system (PEDSLAB, Medical Associated Services, Hatfield, PA, USA), which records airflow and pressure signals, and normalizes them to individual animal weight.

Respiratory permeability was measured directly after recording the pulmonary function characteristics of each animal. Respiratory permeability was determined by calculating the pulmonary clearance of intratracheally instilled ${ }^{99 \mathrm{~m}}$ Tc-labeled diethylenetriaminepentaacetic acid ( $\left.{ }^{99 \mathrm{~m}} \mathrm{Tc}-\mathrm{DPTA}\right)$ over a period of 10 min. using a gamma counter (Ludlum, Sweetwater, TX, USA) and expressed as a $k$ value (\% clearance/ minute).

\section{Morphological Analysis of the Lung}

These methods have also been described in a previous report (Robledo et al., 2000). Immediately following alveolar permeability testing, 3 animals per exposure group ( 2 exposed and 1 control) were randomly assigned for pulmonary morphological evaluation. Anesthetized animals were euthanized by exsanguination of the abdominal aorta, and the lungs were removed and cannulated. Lungs were fixed by intratracheal instillation of half-strength Karnovsky's fixative (2\% paraformaldehyde, $2 \%$ glutaraldehyde, and $0.01 \%$ picric acid in 0.1 M HEPES) at a constant pressure of $20 \mathrm{~cm} \mathrm{H}_{2} \mathrm{O}$ for $1 \mathrm{hr}$. The lungs were then immersed in fixative for $24 \mathrm{hr}$ at $4^{\circ} \mathrm{C}$. Sagittal sections $(2-3 \mathrm{~mm})$ from the fixed lungs were taken from the midportion of the left and right lungs and were minced into $1 \mathrm{~mm}^{3}$ pieces for electron microscopy. Electron microscopy sections (silver to gold interference colors) were prepared by osmication, sectioning, and staining with lead citrate and uranyl acetate. The sections were examined with a Philips CM-12 transmission electron microscope (Mahwah, NJ, USA). Electron micrographs were utilized to measure alveolar type II epithelial and terminal bronchial epithelial pathology.

\section{Morphometric Procedures}

Standard point counting morphometric techniques adapted to the lung (Weibel, 1979) were used. Analysis of electron micrographs was performed as outlined previously (Lantz and Hinton, 1984; Lantz et al., 1985). Briefly, for point counting, electron micrographs were enlarged to $5050 \times$ and $8100 \times$. The test grid, a $19 \times 25$-square lattice ( 520 points per field) with a distance between points of $0.20 \mu \mathrm{m}$ and $0.12 \mu \mathrm{m}$, respectively, was placed over each micrograph. The number of points falling on structures of interests was used to estimate the volume density $\left(\mathrm{V}_{\mathrm{v}}\right)$. In alveolar type II epithelial cells, $\mathrm{V}_{\mathrm{v}}$ of the lamellar bodies/vacuoles was determined. In terminal bronchial epithelial cells, $\mathrm{V}_{\mathrm{v}}$ of vacuoles was determined.

\section{Statistical Analysis}

Significant differences between exposure groups 
and their controls were determined by an analysis of variance. A standard two-tailed $t$-test (Schefler, 1984) for least-significant differences was utilized to determine which groups were significantly different from each other. Statistical analyses were performed with Excel statistical software (Microsoft, Seattle, WA, USA) and $p$ values of less that 0.05 were considered significant (as compared to controls $\left[0 \mathrm{mg} / \mathrm{m}^{3} \mathrm{JP}-8\right]$ ). All data are presented as the mean plus or minus the standard deviation (mean $\pm \mathrm{SD})$.

\section{RESULTS}

Pulmonary Function and Respiratory Permeability At 24 to $30 \mathrm{hr}$ after the final exposure, there were no significant changes in dynamic compliance, airway resistance, or respiratory permeability in either the 45 or the $267 \mathrm{mg} / \mathrm{m}^{3} \mathrm{JP}-8$ exposure groups (Tables 1 and $2)$. In the third exposure group $\left(406 \mathrm{mg} / \mathrm{m}^{3}\right)$ there was a single notable exception of a significant decrease in inspiratory dynamic lung compliance (Table 3).

Table 1. Pulmonary function and respiratory clearance of ${ }^{99 \mathrm{~m}} \mathrm{Tc}-\mathrm{DTPA}$ in mice following repeated inhalation exposures to aerosolized JP-8 at a concentration of $45 \mathrm{mg} / \mathrm{m}^{3}$.

\begin{tabular}{|c|c|c|}
\hline \multirow[t]{2}{*}{ Pulmonary Function } & \multicolumn{2}{|c|}{ JP-8 exposure concentration } \\
\hline & $0 \mathrm{mg} / \mathrm{m}^{3}$ (control) & $45 \mathrm{mg} / \mathrm{m}^{3}$ \\
\hline \multicolumn{3}{|c|}{ Dynamic Lung Compliance $\left(\mathrm{ml} / \mathrm{cmH}_{2} \mathrm{O} / \mathrm{kg}\right)$} \\
\hline Inspiratory & $0.072 \pm 0.009$ & $0.080 \pm 0.017$ \\
\hline Expiratory & $0.062 \pm 0.004$ & $0.066 \pm 0.011$ \\
\hline Total & $0.061 \pm 0.005$ & $0.064 \pm 0.011$ \\
\hline \multicolumn{3}{|c|}{ Total Lung Compliance $\left(\mathrm{ml} / \mathrm{cmH}_{2} \mathrm{O} / \mathrm{kg}\right)$} \\
\hline Inspiratory & $2.825 \pm 0.360$ & $3.233 \pm 0.616$ \\
\hline Expiratory & $2.438 \pm 0.161$ & $2.671 \pm 0.402$ \\
\hline Total & $2.411 \pm 0.173$ & $2.593 \pm 0.414$ \\
\hline \multicolumn{3}{|l|}{ Lung Resistance $\left(\mathrm{cmH}_{2} 0 \cdot \mathrm{kg} / \mathrm{L} / \mathrm{sec}\right)$} \\
\hline Inspiratory & $97.36 \pm 48.38$ & $119.29 \pm 37.78$ \\
\hline Expiratory & $94.58 \pm 52.77$ & $99.99 \pm 73.56$ \\
\hline Total & $50.24 \pm 31.09$ & $45.98 \pm 33.50$ \\
\hline 99mTc-DTPA (\%/min) & $3.11 \pm 0.20$ & $4.28 \pm 1.30$ \\
\hline
\end{tabular}

aMean \pm standard deviation; $n=12$ (exposed); $n=6$ (control).

Table 2. Pulmonary function and respiratory clearance of ${ }^{99 \mathrm{~m}} \mathrm{Tc}-\mathrm{DTPA}$ in mice following repeated inhalation exposures to aerosolized JP-8 at a concentration of $267 \mathrm{mg} / \mathrm{m}^{3}$.

\begin{tabular}{|c|c|c|}
\hline \multirow[t]{2}{*}{ Pulmonary Function } & \multicolumn{2}{|c|}{ JP-8 exposure concentration } \\
\hline & $0 \mathrm{mg} / \mathrm{m}^{3}$ (control) & $267 \mathrm{mg} / \mathrm{m}^{3}$ \\
\hline \multicolumn{3}{|c|}{ Dynamic Lung Compliance $\left(\mathrm{ml} / \mathrm{cmH}_{2} \mathrm{O} / \mathrm{kg}\right)$} \\
\hline Inspiratory & $0.069 \pm 0.012$ & $0.068 \pm 0.008$ \\
\hline Expiratory & $0.064 \pm \quad 0.009$ & $0.070 \pm 0.038$ \\
\hline Total & $0.062 \pm \quad 0.010$ & $0.060 \pm 0.006$ \\
\hline \multicolumn{3}{|c|}{ Total Lung Compliance $\left(\mathrm{ml} / \mathrm{cmH}_{2} \mathrm{O} / \mathrm{kg}\right)$} \\
\hline Inspiratory & $2.747 \pm 0.504$ & $2.912 \pm 0.374$ \\
\hline Expiratory & $2.560 \pm 0.334$ & $2.999 \pm 1.673$ \\
\hline Total & $2.467 \pm 0.380$ & $2.538 \pm 0.383$ \\
\hline \multicolumn{3}{|l|}{ Lung Resistance $\left(\mathrm{cmH}_{2} 0 \cdot \mathrm{kg} / \mathrm{L} / \mathrm{sec}\right)$} \\
\hline Inspiratory & $105.26 \pm 28.49$ & $109.54 \pm 20.50$ \\
\hline Expiratory & $183.71 \pm 170.61$ & $130.70 \pm 52.29$ \\
\hline Total & $89.67 \pm 62.14$ & $74.40 \pm 48.94$ \\
\hline 99mTc-DTPA (\%/min) & $2.81 \pm 1.26$ & $2.12 \pm 1.50$ \\
\hline
\end{tabular}

aMean \pm standard deviation; $n=12$ (exposed); $n=6$ (control). 
A reevaluation of the threshold exposure level of inhaled JP-8 in mice.

Inspiratory dynamic lung compliance was decreased by 20 percent following exposure to $406 \mathrm{mg} / \mathrm{m}^{3} \mathrm{JP}-8$. No other significant changes in dynamic compliance, airway resistance, or respiratory permeability were noted.

\section{General Morphological Findings}

Ultrastructural evaluation of lung tissue focused on alveolar type II epithelial cells and the terminal bronchial epithelium. In response to JP-8 in all of the JP-8 jet fuel exposure groups, examination by electron microscopy showed various alterations in cellular morphology of alveolar type II cells compared to the respective control animals. The most distinguishable of these cellular alterations was the apparent increase in the number and size of surfactant-producing lamellar bodies. However, such alterations did not appear to progress in a dose dependent fashion.

Cellular and ultrastructural alterations in the terminal bronchial epithelium were also observed by electron microscopy. Differences in cytoplasmic vacuolization were observed in the Clara cells of the exposed groups, although distinctions between JP-8 exposure concentration levels were unclear. Additionally, detached cellular debris was observed in the bronchioles, most likely exfoliated bronchiolar epithelium. This sloughing of airway epithelial cells was noticed primarily in JP-8 jet fuel-exposed mice, although significant differences between different exposure con- centrations were not noted. The ciliated epithelial cells situated between the Clara cells did not show significant morphological alternations.

\section{Quantitative Morphometric Findings}

A morphometric analysis of the electron micrographs of the distal lung tissue of the exposed mice confirmed and quantified the apparent morphological alterations noted above. Significant differences in the volume density of surfactant-producing lamellar bodies were found in two of the exposed groups of mice when compared with the control animals (Table 4). The $45 \mathrm{mg} / \mathrm{m}^{3}$ and $406 \mathrm{mg} / \mathrm{m}^{3} \mathrm{JP}-8$ exposure groups each showed a 36 percent increase in lamellar body volume density in type II cells. However, this increase was not found to be dose-dependent.

Morphometric techniques applied to the electron micrographs of the terminal bronchial epithelium did not show significant differences in the volume density of cytoplasmic vacuoles in the Clara cells (not shown), the major cellular alteration noted in the general morphological findings.

Our new "in-line, real-time" JP-8 jet fuel exposure system measures both aerosol and vapor component whereas our previous JP-8 jet fuel exposure system was only able to measure the JP-8 jet fuel aerosol component. We have calculated a correction factor of 8.1 based on pathological analysis of the magnitude of lung injury. In other words, in our previously published

Table 3. Pulmonary function and respiratory clearance of ${ }^{99 \mathrm{~m}} \mathrm{Tc}-\mathrm{DTPA}$ in mice following repeated inhalation exposures to aerosolized JP-8 at a concentration of $406 \mathrm{mg} / \mathrm{m}^{3}$.

\begin{tabular}{|c|c|c|}
\hline \multirow[t]{2}{*}{ Pulmonary Function } & \multicolumn{2}{|c|}{ JP-8 exposure concentration } \\
\hline & $0 \mathrm{mg} / \mathrm{m}^{3}$ (control) & $406 \mathrm{mg} / \mathrm{m}^{3}$ \\
\hline \multicolumn{3}{|c|}{ Dynamic Lung Compliance $\left(\mathrm{ml} / \mathrm{cmH}_{2} \mathrm{O} / \mathrm{kg}\right)$} \\
\hline Inspiratory & $0.094 \pm 0.003$ & $0.075 \pm 0.012 *$ \\
\hline Expiratory & $0.069 \pm 0.005$ & $0.065 \pm 0.006$ \\
\hline Total & $0.071 \pm 0.013$ & $0.067 \pm 0.008$ \\
\hline \multicolumn{3}{|c|}{ Total Lung Compliance $\left(\mathrm{ml} / \mathrm{cmH}_{2} \mathrm{O} / \mathrm{kg}\right)$} \\
\hline Inspiratory & $3.378 \pm 0.418$ & $2.892 \pm 0.633$ \\
\hline Expiratory & $2.465 \pm 0.404$ & $2.478 \pm 0.348$ \\
\hline Total & $2.555 \pm 0.616$ & $2.544 \pm 0.351$ \\
\hline \multicolumn{3}{|l|}{ Lung Resistance $\left(\mathrm{cmH}_{2} \mathrm{O} \cdot \mathrm{kg} / \mathrm{L} / \mathrm{sec}\right)$} \\
\hline Inspiratory & $104.39 \pm 23.66$ & $112.30 \pm 76.56$ \\
\hline Expiratory & $73.82 \pm 34.66$ & $113.56 \pm 60.35$ \\
\hline Total & $82.46 \pm 40.84$ & $87.28 \pm 57.34$ \\
\hline 99mTc-DTPA (\%/min) & $2.73 \pm 2.04$ & $3.28 \pm 1.74$ \\
\hline
\end{tabular}

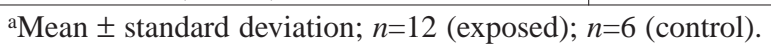

$*$ Statistically significant difference from control group mean; $p<0.05$. 


\section{B. R. HERRIN et al.}

work, one must multiply the average JP-8 jet fuel concentration 8.1 to account for the unmeasured vapor component.

\section{DISCUSSION}

The short-term effects of JP-8 jet fuel inhalation on male $\mathrm{C} 57 \mathrm{BL} / 6$ mice were investigated to confirm the cytotoxic effects and induced lung injury at JP-8 exposure concentrations at and below the current PEL of $350 \mathrm{mg} / \mathrm{m}^{3}$, observations that were shown in earlier studies. In the present study, it was observed that inhalation exposure to JP-8 concentrations below the established PEL can induce initial signs of cellular damage in the distal lungs. Significant changes at the cellular level, quantified by morphometric analysis techniques, occurred at JP-8 exposure concentrations as low as 45 $\mathrm{mg} / \mathrm{m}^{3}$, a concentration level less than 15 percent of the current PEL concentration. In conjunction with the previous study (Robledo et al., 2000) and the report that US Air Force personnel are occupationally exposed to respiratory aerosols of JP- 8 in addition to JP-8 vapors, this study provides further evidence that the vapor-based PEL and STEL should be reevaluated with regard to respiratory aerosols.

JP-8 exposure did not cause significant changes in pulmonary function tests at any of the exposure concentrations with the exception of a significant decrease in inspiratory dynamic lung compliance at the highest concentration of $406 \mathrm{mg} / \mathrm{m}^{3}$. Initially, this observation is compatible with the current PEL. Should the PEL be accurate, physiological changes indicative of lung injury would not be expected. However, evaluation of the respiratory structures in the exposed animal models using a more sensitive index to assess lung damage showed signs of initial cellular alteration and damage in both alveolar type II epithelial cells and the terminal bronchial epithelium. These cellular changes coincide with those observed in the previously mentioned study (Robledo et al., 2000). In that study, both types of cells were found to be sentinel markers of initial cellular damage in the lung tissue due to JP- 8 exposure. In addition, this initial targeting of the terminal airways is in agreement with prior findings of two other studies that examined the effects of kerosene aspiration. Both observed initial detrimental effects in the terminal airways (Scharf et al., 1981; Scharf and Prinsloo, 1982). This previous work correlates with the current study, as JP-8 is a kerosene-based fuel. Therefore, despite the near-absence of physiological changes at exposure concentrations below the established PEL, significant alterations and damage occurred at the cellular level.

Based on the morphological evidence and morphometric data presented in the present study, compensatory effects within the lung are hypothesized to have taken place. The early cellular/tissue-level damage observed has an initial detrimental effect on pulmonary function. The lungs are able to initially compensate for decreased pulmonary ability by increasing surfactant production in the alveolar type II cells. Surfactant acts to reduce the surface tension throughout the lungs, but specifically of the alveolar-capillary surface, thus increasing pulmonary performance. This compensatory mechanism is supported by past studies that have investigated smoke-induced epithelial damage and have suggested that type II epithelial cells are capable of compensating for lung injury by increasing surfactant production (Wang et al., 1999). The noted increases in the size and/or number (volume density measurements do not distinguish between increased size and quantity) of lamellar bodies in type II cells is evidence of increased surfactant production. Thus, despite initial lung injury on the cellular level, pulmonary function tests would not show differences because such measurements on a physiological level are not sensitive enough.

Table 4. Volume density of surfactant-producing lamellar bodies in alveolar type II epithelial cells in mouse distal lung.

\begin{tabular}{|l|c|l|}
\hline & $N$ & \multicolumn{1}{|c|}{ Volume density } \\
\hline Control $\left(45 \mathrm{mg} / \mathrm{m}^{3}\right)$ & 13 & $0.179 \pm 0.055$ \\
\hline $45 \mathrm{mg} / \mathrm{m}^{3}$ & 16 & $0.243 \pm 0.085^{*}$ \\
\hline Control $\left(267 \mathrm{mg} / \mathrm{m}^{3}\right)$ & 9 & $0.181 \pm 0.040$ \\
\hline $267 \mathrm{mg} / \mathrm{m}^{3}$ & 19 & $0.163 \pm 0.082$ \\
\hline Control $\left(406 \mathrm{mg} / \mathrm{m}^{3}\right)$ & 9 & $0.162 \pm 0.079$ \\
\hline $406 \mathrm{mg} / \mathrm{m}^{3}$ & 19 & $0.221 \pm 0.077^{*}$ \\
\hline
\end{tabular}

${ }^{\mathrm{a}}$ Mean \pm standard deviation.

*Statistically significant difference from control group mean; $\mathrm{p}<0.05$. 
A reevaluation of the threshold exposure level of inhaled JP-8 in mice.

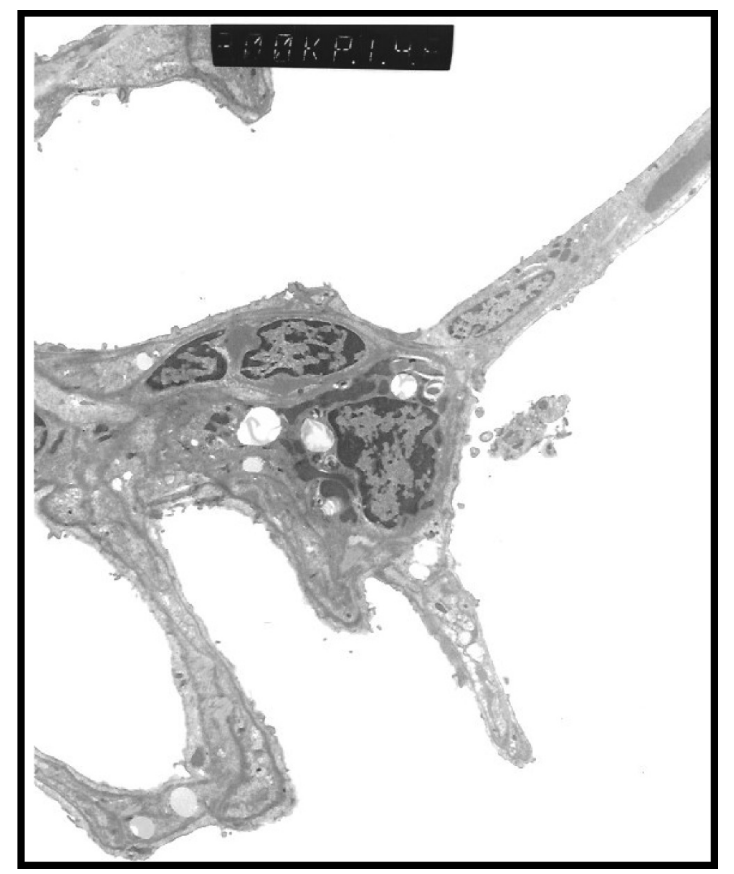

Photo 1. A representative example of a transmission electron micrograph of an alveolar type II epithelial cell from a control mouse. Note the surfactant-producing lamellar bodies.

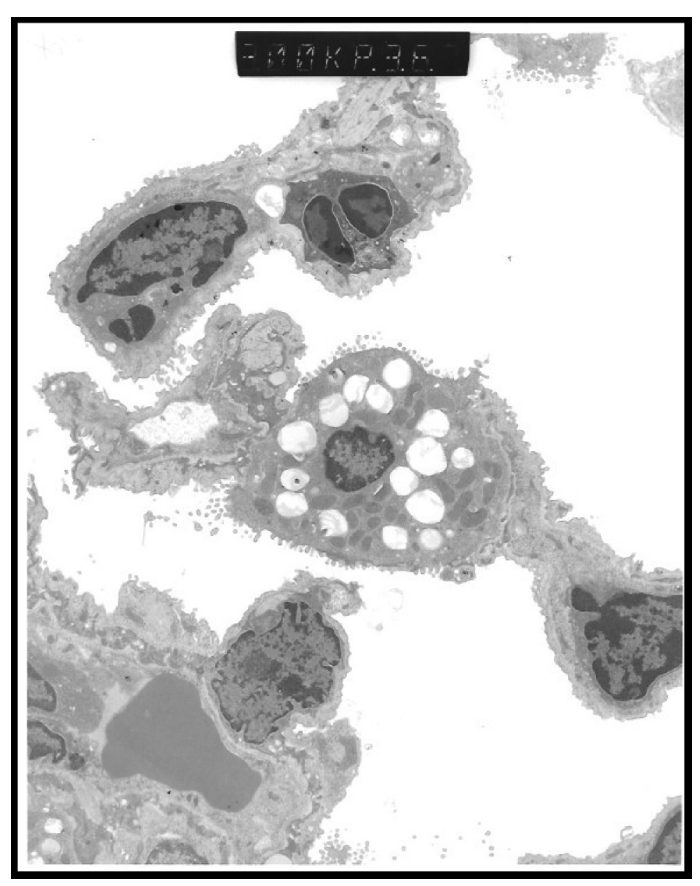

Photo 3. A representative example of a transmission electron micrograph of an alveolar type II epithelial cell from the $267 \mathrm{mg} / \mathrm{m}^{3} \mathrm{JP}-8$ exposure group.

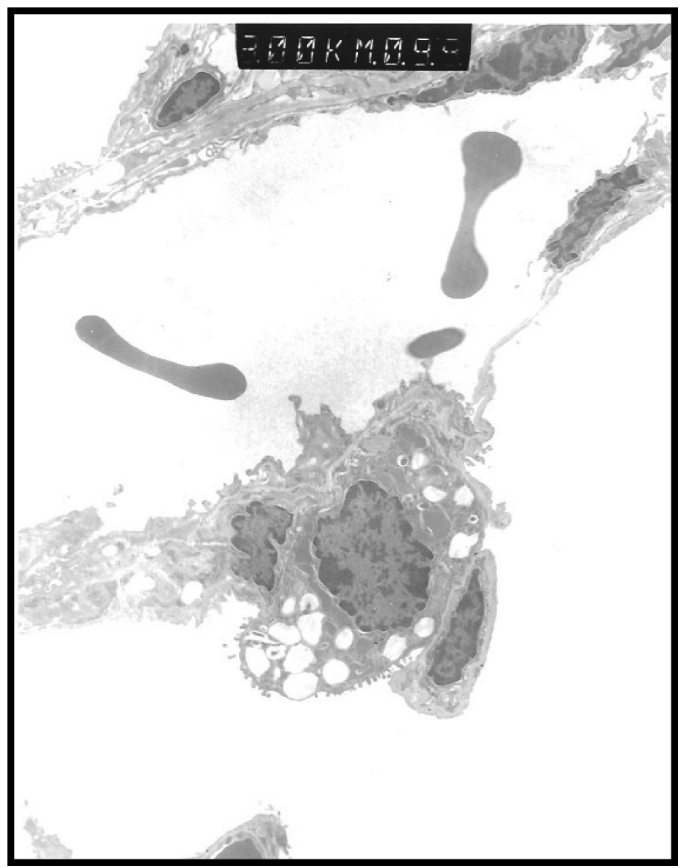

Photo 2. A representative example of a transmission electron micrograph of an alveolar type II epithelial cell from the $45 \mathrm{mg} / \mathrm{m}^{3} \mathrm{JP}-8$ exposure group. Note the apparent increase of surfactant-producing lamellar bodies.

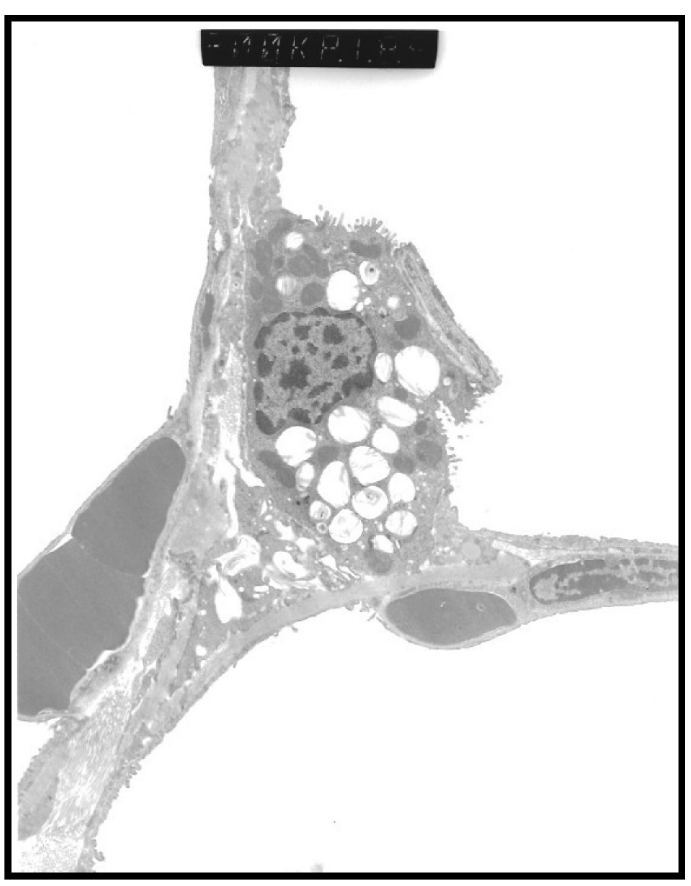

Photo 4. A representative example of a transmission electron micrograph of an alveolar type II epithelial cell from the $406 \mathrm{mg} / \mathrm{m}^{3} \mathrm{JP}-8$ exposure group. Note the apparent increase of surfactant-producing lamellar bodies. 
B. R. HERRIN et al.

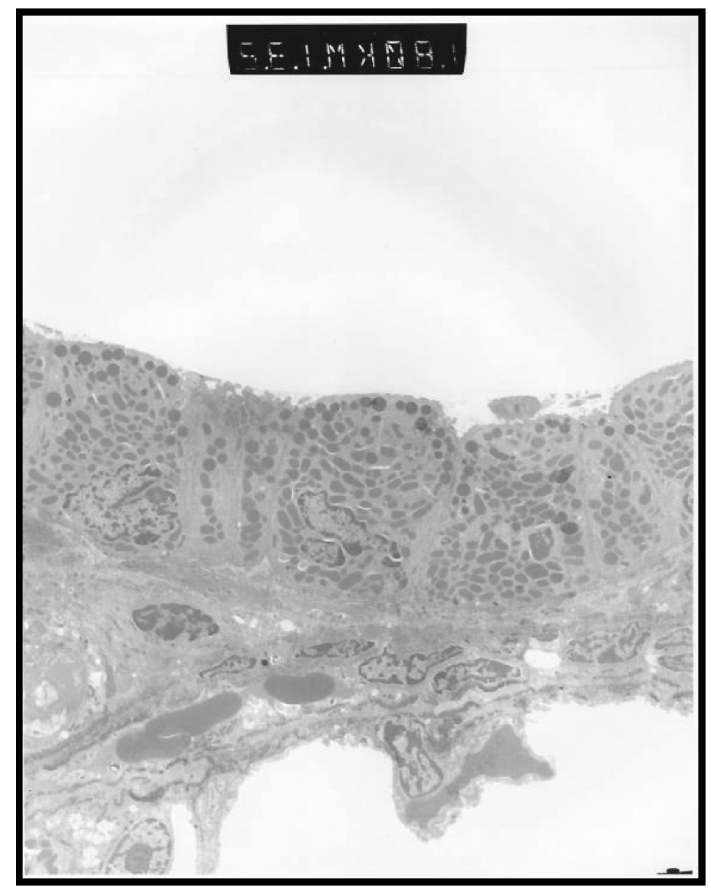

Photo 5. A representative example of a transmission electron micrograph of the terminal bronchiolar epithelium from a control mouse.

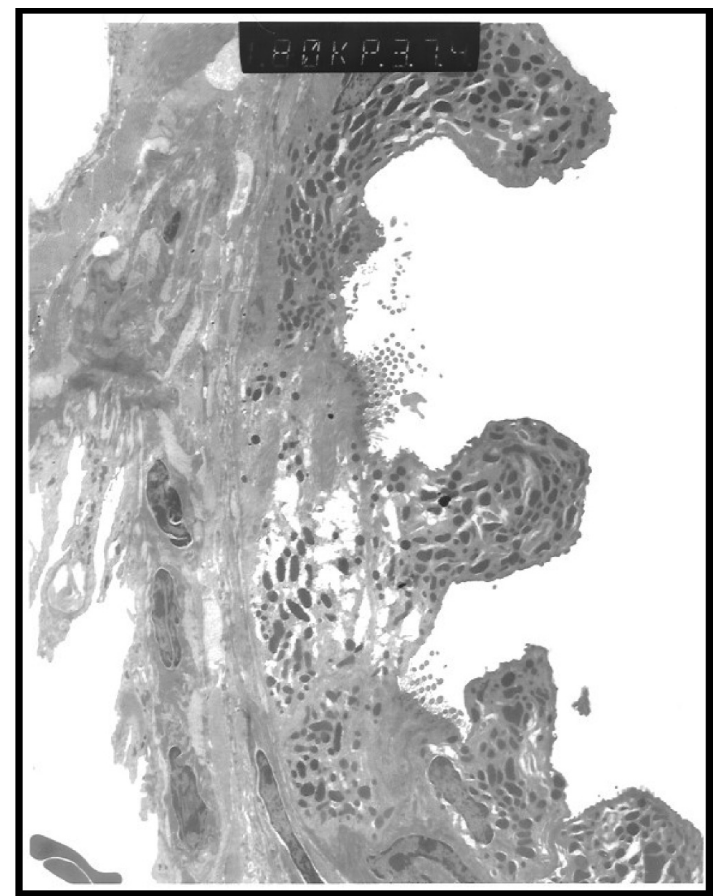

Photo 7. A representative example of a transmission electron micrograph of the terminal bronchiolar epithelium from the $267 \mathrm{mg} / \mathrm{m}^{3} \mathrm{JP}-8$ exposure group.

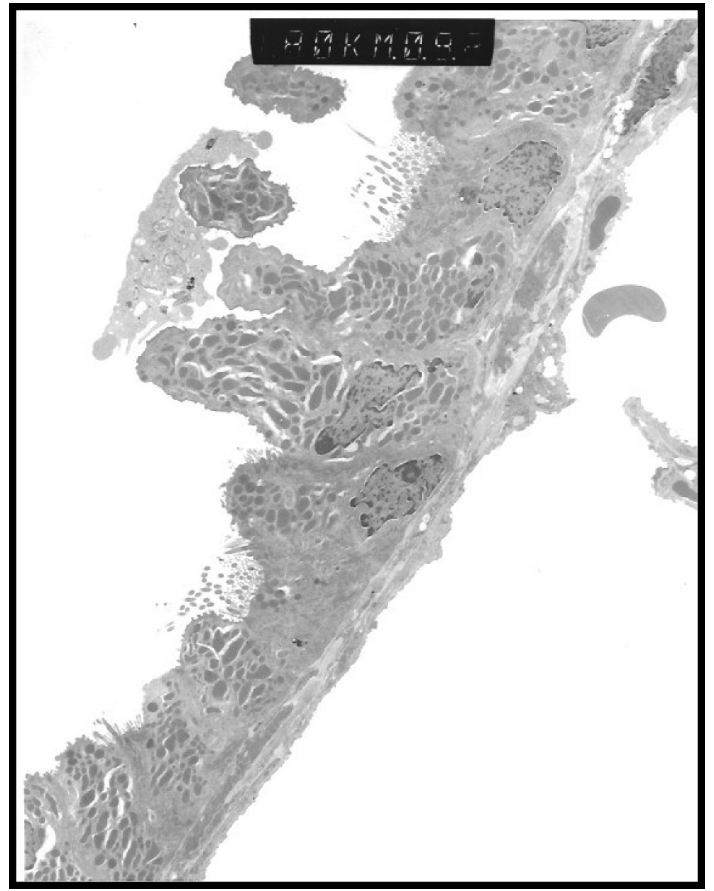

Photo 6. A representative example of a transmission electron micrograph of the terminal bronchiolar epithelium from the $45 \mathrm{mg} / \mathrm{m}^{3} \mathrm{JP}-8$ exposure group.

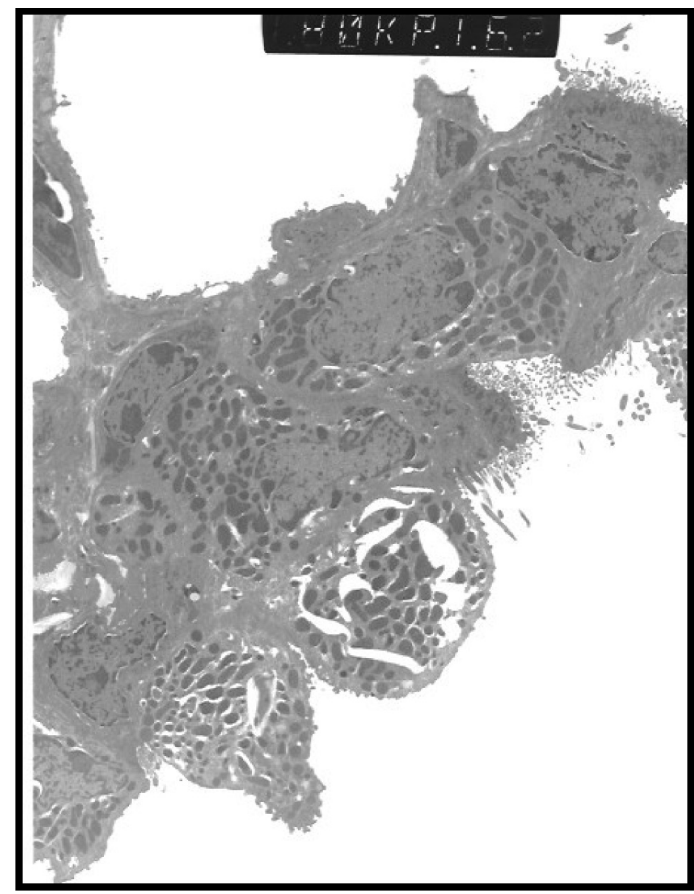

Photo 8. A representative example of a transmission electron micrograph of the terminal bronchiolar epithelium from the $406 \mathrm{mg} / \mathrm{m}^{3} \mathrm{JP}-8$ exposure group. 
A reevaluation of the threshold exposure level of inhaled JP-8 in mice.

This trend is supported by the morphological data observed in this study, specifically in type II cells. At concentrations of $45 \mathrm{mg} / \mathrm{m}^{3}$ and $267 \mathrm{mg} / \mathrm{m}^{3}$, neither showed significant changes from a pathological viewpoint. However, at a cellular level, morphological changes were observed. Of special interest, a significant increase in the volume density of lamellar bodies present in type II cells was observed at $45 \mathrm{mg} / \mathrm{m}^{3}$ in the morphometric data. Subsequently, at a concentration of $406 \mathrm{mg} / \mathrm{m}^{3}$, initial physiological changes were observed (decrease in inspiratory dynamic compliance), in addition to the morphological changes that were observed at lower concentrations. Further, one would anticipate that biochemical indices would detect levels of toxicity with a greater sensitivity than the morphological/morphometric analysis techniques, pulmonary function, or respiratory permeability tests.

JP-8 inhalation studies need to be designed in order to further investigate the use of morphological and morphometric analysis techniques for detecting the deleterious effects of JP-8 inhalation at concentrations below the current PEL. Such techniques appear to provide an increased sensitivity as compared to the physiological evidence offered by pulmonary function or respiratory permeability tests. In addition, a similar study to the present one should be designed to specifically determine, if any, changes in surfactant production. Other biochemical markers may also be indicative of cellular compensatory mechanisms. Such information would be valuable in better understanding the lungs' ability to adapt to physical and chemical stressors from the outside environment. In summary, based on the results of this study, we suggest that the current $350 \mathrm{mg} / \mathrm{m}^{3}$ PEL for both JP-8 jet fuel and for other more volatile petroleum distillates be reevaluated and a lower, more accurate PEL be established with regard human occupational exposure limits.

\section{ACKNOWLEDGMENT}

We thank Brian Barbaris and Peggy McCuskey for their technical assistance. This research was supported by a grant from the U.S. Air Force Office of Scientific Research. (F49620-00-1-0119).

\section{REFERENCES}

Agency for Toxic Substances and Disease Registry (1995): Toxicological profile for jet fuels JP-4 and JP-7. Agency for Toxic Substances and Disease Registry, Atlanta, GA.
Cooper, J.R. and Mattie, D.R. (1996): Developmental toxicity of JP-8 jet fuel in the rat. J. Appl. Toxicol., 16, 197-200.

Dietzel, K.D., Campbell, J.L., Bartlett, M.G., Witten, M.L. and Fisher, J.W. (2005): Validation of a gas chromatography mass spectroscopy (GC/ MS) method for quantification of aerosolized jet propellant (JP-8). Journal of Chromatography Analysis., 1093, 11-20.

Dossing, M., Loft, S. and Schroeder, E. (1985): Jet fuel and liver function. Scand J. WorkEnviron. Health., 11, 433-437.

Drake, M.G., Witzmann, F.A., Hyde, J. and Witten, M.L. (2003): JP-8 jet fuel exposure alters protein expression in the lung. Toxicology., 191, 199-210.

Hays, A.M., Parliman, G., Pfaff, J.K., Lantz, R.C., Tinajero, J., Tollinger, B., Hall, J.N. and Witten, M.L. (1995): Changes in lung permeability correlate with lung histology in a chronic exposure model. Toxicol. Ind. Health., 11, 325-336.

Harris, D.T., Sakiestewa, D., Robledo, R.F. and Witten, M.L. (1997a): Immunotoxicological effects of JP-8 jet fuel exposure. Toxicol. Ind. Health., 13, 43-55.

Lantz, R.C., Hinton, D.E. (1984): Pulmonary Toxicity Associated with Fly Ash from Fluidized Bed Coal Combustion. Toxicol. Appl. Pharm., 75, 44-51.

Lantz, R.C. and Birch, K., Hinton, D.E. and Burrell, R. (1985): Morphometric Changes of the Lung Induced by Inhaled Bacterial Endotoxin.

Martel, C.R. (1987): Military jet fuel, 1944-1987 summary report. AFWAL-TR-87-2062. Dayton, OH. Aero Propulsion Laboratory, AFWAL, AFSC, Wright-Patterson Air Force Base.

National Research Council (1996): Permissible exposure levels for selected military fuel vapors. National Research Council, National Academy Press, Washington, DC.

Pfaff, J., Parton, K., Lantz, R.C., Chen, H., Hays, A. and Witten, M.L. (1995): Inhalation exposure to JP-8 jet fuel alters pulmonary function and substance P levels in Fischer 344 rats. J. Appl. Toxicol., 15, 249-256.

Pfaff, J., Tollinger, B.J., Lantz, R.C., Chen, H., Hay, A. and Witten, M.L. (1996): Neutral endopeptidase (NEP) and its role in pathological pulmonary change with inhalation exposure to JP-8 jet fuel. Toxicol. Ind. Health., 12, 93-103.

Pleil, J.D., Smith, L.B. and Zelnick, S.D. (2000): Per- 
B. R. HERRIN et al.

sonal exposure to JP-8 jet fuel vapors and exhaust at Air Force Bases. Environ. Health Perspectives., 108, 183-192.

Robledo, R.F. and Witten, M.L. (1998): Acute pulmonary response to inhaled JP-8 jet fuel in mice. Inhal. Toxicol., 10, 531-553.

Robledo, R.F., Young, R.S., Lantz, R.C. and Witten, M.L. (2000): Short-term pulmonary response to inhaled JP8 jet fuel aerosol in mice. Toxicol. Pathol., 28, 656-663.

Scharf, S.M., Heimer, D. and Goldstein, J. (1981): Pathologic and physiologic effects of aspiration of hydrocarbons in the rat. Am. Rev. Respir. Dis., 124, 625-629.

Scharf, S.M. and Prinsloo, I. (1982): Pulmonary mechanics in dogs given doses of kerosene intratracheally. Am. Rev. Respir. Dis., 126, 695700.

Schefler, W.C. (1984): Statistics for Health Professionals. Addison-Wesley Publishing Company, Reading, MA.
Smith, L.B., Bhattacharya, A., Lemasters, G., Succop, P., Puhala, H.E., Medvedovic, M. and Joyce, J. (1997): Effect of chronic low-level exposure to jet fuel on postural balance of US Air Force personnel. J. Occup. Environ. Med., 39, 623-632.

Ullrich, S.E. (1999): Dermal application of JP-8 jet fuel induces immune suppression. Toxicol. Sci., 52, 61-67.

Wang, S., Lantz, R.C., Robledo, R.F., Breceda, V., Hays, A.M. and Witten, M.L. (1999): Early alterations of lung injury following acute smoke exposure and 21-aminosteroid treatment. Toxicol. Pathol., 27, 334-341.

Wang, S., Young, R.S. and Witten, M.L. (2001): Agerelated differences in pulmonary inflammatory responses to JP-8 jet fuel aerosol inhalation. Toxicol. Ind. Health., 17, 23-29.

Weibel, E.R. (1979): Stereological Methods, Vol. 1, Practical Methods for Biological Morphometry. Academic Press, New York. 